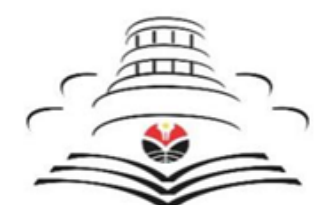

JURNAL UPI
THE JOURNAL GASTRONOMY TOURISM

Volume 6 Issue 2, December 2019, 131-145

Tersedia daring di:

https://ejournal.upi.edu/index.php/gastur

\title{
Preservation of Kejek Tea as a Gastronomic Legacy of Garut Regency
}

\author{
Sarah Nur Hamidah ${ }^{1}$, Dewi Turgarini ${ }^{1}$, Indriyani Handyastuti ${ }^{2}$ \\ ${ }^{1}$ Indonesia University of Education, Jl. Dr. Setiabudhi No. 229, Bandung 40154, Indonesia \\ ${ }^{2}$ NHI Tourism Academy, Jl. Raya Lembang KM 12.8, Kabupaten Bandung Barat 40391, \\ Indonesia \\ *Corresponding Author. E-mail: sarahnurhamidah70@gmail.com (Sarah Nur Hamidah)
}

\begin{tabular}{|l} 
ABSTRACT \\
Kejek tea is a traditional Cigedug tea. The purpose of this research is to know the existence, \\
how to make tea in a traditional way, how to drink Kejek Tea and describe the tea Keek into a \\
gastronomic tourist attraction in Garut Regency. The research method used is a descriptive \\
qualitative research. The method for obtaining data is by conducting in-depth interviews, \\
observation and documentation. Cigedug Village, Garut as a place to do research activities. The \\
results of this study can be seen that: (1) Kejek tea has existed since the Dutch era in the 1900s. (2) \\
How to manufacture that is still done manually using foot power and traditional tools. (3) Kejek \\
Tea has a tradition of drinking tea, namely Nyaneut Tradition. (4) Kejek Tea has the potential is \\
high enough to be a product that can increase income for the surrounding community if it is able \\
to be developed or managed properly. Efforts to preserve traditional tea must be done not only by \\
producers, the government but must also involve all elements of society. \\
Keywords: Kejek Tea; Existance; Preservation; Traditional; Gatronomy Tourism; Garut \\
First Received: June 2019 Revised: August $2019 \quad$ Accepted: August 2019 \\
Final Proof Received: December 2019 \\
\hline \hline
\end{tabular}




\section{Introduction}

Indonesia is one of the countries with tourism areas that have an attraction for domestic and international tourists. Various kind of tourist attractions in Indonesia participate in tourism industry development in Indonesia. Existing diversity gives tourists the choice to choose which areas will become tourist destinations.

According to the Republic of Indonesia (2009) on Tourism in Article 1, Tourism is a variety of tourism activities and supports various facilities and services provided by the community, business people, government, and regional government. Salah Wahab (2003: 5) states that tourism is one of the new style industries, which is able to provide rapid economic growth in terms of employment opportunities, income, standard of living, and in activating other sectors in the tourist reception country.

One type of tourism that is relatively new is gastronomic tourism, Chaney \& Ryan (2012). Gastronomy tourism (gastronomy tourism) as part of cultural tourism in NIOS (2018) is a type of tourism that is designed with the main purpose of making food and drinks as the main motivating factor for someone to take the trip.

Garut is one of the gastronomic tourist destinations in Indonesia, one of which is the Kejek Tea gastronomic tour. Kejek tea is a typical Cigedug tea whose processing is still done manually and uses traditional tools. Unlike the other tea places that already use heating and grinding machines that are driven by electricity, Kejek Tea producers, now only leaves one Kejek Tea factory, therefore there is a need for conservation efforts to be undertaken.

The tea commodity boom that did not last long caused the quality of tea to decline. The low price of tea is thought to be one of the causes. Tea becomes a business that is not profitable for farmers. This causes many farmers to abandon the garden. Some farmers prefer to replace them with vegetable crops which are considered more profitable.

This condition is exacerbated by the poor Pascapanen treatment of the remaining tea plantations. If the previous picking buds of tea leaves are done carefully by hand, now some farmers are tempted to use a cutting machine for efficiency reasons. Not infrequently there are farmers who cut down tea using machetes. All this results are in difficulty getting good raw tea quality.

The advantage of Kejek tea is in the traditional manufacturing process, that is by mocking (trampled). This tea has a distinctive flavor and aroma of tea. Although traditionally made, many are fond of Kejek tea. This favorite even slowly creates a new tea habit, namely Nyaneut tradition. The tradition of tea drinking is useful for warming up the body in the cold night air. A tea commodity Boom that did not last long caused the tea quality to decline. Low tea Price is considered one of the causes. Tea becomes a business that is not profitable for farmers for it causes many farmers to leave the garden. Some farmers prefer to replace it with vegetable plants that are considered more beneficial.

This makes many of Kejek tea manufacturing efforts in both Cigedug and Cikajang closed. In Cigedug, now left only one Kejek tea production that is owned by Pak Oos family. Previously, there were hundreds of tea-making businesses. Mr. Oos believes that this effort should be continued because it can provide a better livelihood for local people. In addition, Kejek tea has a distinctive flavor compared to other teas. This makes Kejek tea has its own market. The Kejek tea is also a reminder of the success of the tea business in the Cikajang and Cigedug areas of the past. Hope is that people will be motivated to grow this business again

\section{Literature Review}

2.1 Gastronomy

According to Dewi Turgarini (2018: 19-20), Gastronomy (gastronomy) is an art 
and science, even appreciation that is cross-ethnic, racial, group, religious, gender and cultural by studying in detail eating, food, and drinks to be used in various conditions and situations.

Dewi Turgarini also (2018: 20) emphasizes that food is a core component of every culture. As part of culture, authentic eating (authenticity) is a combination of Eagleton (1997) pleasure, utility, and social, while food is a dictionary of moods and sensations of Ellmann (1993), so the relationship between humans and their food is typical.

Then Dewi Turgarini \& Heni Pridia Rukmini Sari (2017: 28) gastronomy as a differential has practical fields of study (conversion of food into food), theoretical (closely with food science) and technical (performance, performance, system evaluation), and product development food itself, molecular (physio-chemical transformation of food, geography, history, tourism, and so on).

Gastronomic components according to Dewi Turgarini (2018), in gastronomy component is not just focused on how the cooking or culinary, but on human behavior, including selecting the raw material, then taste, feel, serving dishes and the experience of consuming as well as finding, studying, researching and write about food and everything related to human nutrition knowledge in every nation and country, philosophy, history, tradition and social, ethics and etiquette (Shenoy (2005), Manolis (2010), Santich (2010), Pullphothong \& Sopha (2013) in (Dewi Turgarini, 2018).

The engine driving the gastronomic model in Dewi Turgarini (2018: 212) the second level is on three things, namely the taste and aroma, then the variety of food and how to package, serve, and finally to maintain good sanitation and hygiene in food raw materials, the processing method and the location of the marketing place. All three need continuous improvement.

According to Caria Ningsih \& $R$.
Nuraeni (2018: 43), the activation of gastronomic tourism means tourists revolve around food, experience new tastes, and explore culture or history into gastronomic tourism.

But it is unfortunate, today the existence of Kejek Tea in this case is a part of gastronomy inferior to various other types of drinks. Therefore the need for preservation to increase the existence of Kejek Tea.

\subsection{Existence}

According to Muhammad Nastain (2007: 23-24), the existence of the product applies in several elements:

\subsubsection{Packaging (K Golds)}

According to the Official and Wismiarsi (2015: 3), said the packaging can be interpreted as an object that serves to protect, secure certain products in it, and can provide a certain image to persuade its users. Modern distribution systems and trade techniques require that products can be identified at a glance. Information that is expected to be displayed on the packaging includes:

a. Brand name identity :

The benefits of the brand according to Kotler and Keller (2009: 259) are as follows:

1) Simplify product handling or tracing

2) Helps organize inventory records and accounting records

3) Offering legal protection to companies for features or aspects of product units. For companies, the brand presents a valuable piece of legal property, can influence consumers, can be bought and sold, and provides lasting income security.

Meanwhile brand names have functions or uses to facilitate consumers in identifying products that can meet their needs. The requirements for choosing a brand name according to Buchari Alma (2007: 150) are:

1) Easy to remember

2) Making a positive impression 
3) Right for promotion

b. A brief description of the product

According to Iwan Wirya (1999: 28-30), topography is the text on the packaging in the form of our messages to explain the products offered while leaving consumers to behave and act in accordance with producer expectations. The functions of the packaging itself according to Titik Wijayanti (2012), are:

1) Can make beautiful a product with packaging that fits the product category.

2) Provide product safety so that it is not damaged when displayed.

3) Provide product safety during the distribution process.

4) Provide information to consumers about the product itself in the form of labeling.

5) Product design results that indicate the product.

a. Fill, weight or volume

The form of packaging according to Iwan Wirya (1999: 28-30), adjusted to the product, the considerations used are mechanical considerations, sales conditions, sales development, spawning and ways of using the packaging. The forms of packaging are:

1) Simple shapes are preferred over complicated ones

2) Regular shape has more appeal

3) The form must be balanced in order to be pleasant

4) The shape of a square is preferred over a rectangle

5) Convex shape is preferred over concave shape

6) The round shape is preferred by women, while the elbow shape is preferred by men

7) The form must be easily seen when viewed from afar

b. Company, logo, and manufacturer's name

The function of company logo is to increase consumer appeal. This brand or logo is seen as raising the prestige or status of a buyer. The requirements for a good logo according to Wirya (1999: 28-30) are:

1) Contains authenticity

2) Easy to read or pronounce

3) Easy to remember

4) Simple and concise

5) Does not contain negative connotation difficult to describe

c. User guide

User guide is used to find out how to use or present a product.

d. Price

As for prices according to Monroe KB (1990), prices are economic sacrifices made by consumers to get products or services. In addition, price is one of the important factors for consumers in making decisions in making or not conducting transactions.

e. Expired date

Expired date is the maximum limit date on which the product can be consumed. Then to improve the accuracy of product data, it is necessary to have a barcode system.

\subsubsection{Product segment (Market Segmentation)}

Market segmentation, according to Sofjan Assuari (2008: 144), states that market segmentation is a way to differentiate markets according to the group of buyers, user needs, motives, behavior, and buying habits, how to use the product and the purpose of purchasing the product.

Through market segmentation, limited resources can be used optimally to produce products that can meet market demand, can allocate them to the most profitable potential, and can compete in certain market segments, and can determine effective promotion methods.

According to Caria Ningsih (2014), the creative industry is currently receiving special attention because it is considered capable of contributing to national and regional income and sufficiently able to absorb the workforce, there are three parties involved in the three pillars supporting the creative economy.

Kejek Tea existence is very necessary to 
maintain the existence of tea. This is in accordance with tea according to Laura C. Martin (2007: 23), in the book Tea: The drink that changed the world guessed was first consumed at the beginning of the Paleolithic period around 5000 years ago. Likewise with world archaeologists who indicate that in the same period, the leaves of Camellia Sinensis were first boiled by Homoerectus in an area now known to China.

\subsubsection{Tea Plants}

According to Ali Khomsan (2006), tea is an infusion made by brewing leaves, shoots, or leaf stems dried from the Camellia Sinensis plant using hot water. The tea leaves (Camellia Sinensis) has two varieties: Camellia Sinensis Sinesis and Camellia Sinensis Assamica. The difference is in polyphenol content. It causes a difference between Sinensis and Assamica in terms of taste. Sinensis has a taste character that is a little sepat sweet and soft (sometimes it feels fishy and fishy-smelling). While Assamica has a sepat character and tends to be bitter. $\mathrm{He}$ also stated that there are four (4) types of tea: Oolong tea, black tea, green tea, and white tea.

\subsubsection{Oolong tea}

Oolong tea is a tea resulting from enzymatic semioxidation, also known as not having long contact with air when it is processed. Oolong tea is located between green tea and black tea. Fermentation occurs but only in $(30-70 \%)$ part. The result, the color of the tea becomes reddish brown.

\subsubsection{Green tea}

Green tea according to Sujayanto (2008: 34-38) is processed without oxidation, and does not give the opportunity for fermentation. After wilting the tea leaves are rolled, dried and ready to be packed. Usually the buds are processed directly with hot steam (steam) or fried (pan frying) to stop the enzyme activity. The green color persists and the tannin content is relatively high. Green tea is believed able to reduce body weight. This is due to the high polyphenol content. Green tea is a favorite of people in Japan and Korea. Even in Japan there are a variety of green teas such as gyokuro, sencha, kabusecha and konacha, each of which is differentiated based on the manufacturing process. Green tea is appropriate when enjoyed in many activities because it is believed to increase concentration, so it is not suitable to drink before going to bed.

\subsubsection{Black Tea}

Sujayanto (2008: 34-38) states that black tea is obtained from the results of milling which causes the leaves to hurt and secrete the sap. The sap is in contact with air to produce compounds tea flavin and tea rubugin . That is, the tea leaves undergo a perfect chemical change so that all the contents of the catechins are fermented into tea flavin and tea rubugin. The green color will turn brown and during the drying process will turn black. Black tea is most widely known and widely consumed.

\subsubsection{White Tea}

Then Sujayanto (2008: 34-38) states that White Tea is believed to have much more benefits than green tea. From this tea is taken from the leaves that are still rolled up which has the highest content of catechins and caffeine.

The content of tea according to Andi Nur Alam Syah (2006), is as follows:

a. Phenol Substance: polyphenols, flavanols

b. Non-Phenol Substance: kabohydrate

c. Pectin Substance: alkaloids, proteins and amino acids, organic acids

d. Resin Substance: vitamins C, K, A , B1, and B2

e. Mineral substances: magnesium, potassium, flour, calcium

f. Substance Causes of Aroma: Catechins

Tea leaf picking according to Setiawan (2009), is the activity of picking tea leaves / buds consisting of buds, young twigs, and leaves. The picking activity besides aiming 
to collect crop yields in accordance with the processing objectives, is also an effort to shape the condition of the plants so that they can increase sustainable production. A good time for picking tea is in the morning, because the air in the morning is still clean and has not been contaminated with evil substances.

There are many benefits of tea for physical health according to Dian Sundari (2009: 198 ), these benefits include:

a. Tea has the ability to inhibit cancer formation

b. Tea can prevent heart disease and stroke

c. Green tea can prevent influenza attacks

d. Can strengthen teeth, fight bacteria in the mouth, and prevent osteophorosis

e. In the digestive tract, tea helps fight food poisoning

f. Tea can reduce cholesterol levels, blood glucose and reduce liver damage

Tea can improve sleep quality. Chamomile tea is the right choice before going to sleep because, besides helping to cause drowsiness, chamomile also makes the mind in general calmer, so sleep more soundly.

Along with the times, tea enthusiasts are decreasing because of the number of modern drink competitiveness. In order for Kejek Tea to remain and not extinct, it is necessary to preserve efforts to preserve Kejek Tea.

\subsubsection{Preservation}

Conservation according to Chaedar (2006: 18), is a grounded effort, and this basis is also called as the factors that support it both from within and from outside of the thing that is preserved. Therefore, a conservation process or action recognizes strategies or techniques that are based on their individual needs and conditions.

Based on definition above, it can be concluded that preservation and preservation activities are an effort to create an object or a product that is created in order to last long and not change by developing continuously, directed and integrated, in order to realize certain goals can be done through aspects human stabilization, and reflecting one's dynamics.

Various researches and the term conservation try to be expressed by experts in seeing problems that arise based on their own concepts and perceptions. Following statements from the experts:

a. Nia Kurniasih Pontoh (1992: 36), argues that the initial concept of preservation is conservation, which is an effort to preserve and protect while utilizing the resources of a place by adapting to new functions, without losing the meaning of cultural life.

b. Eko Budiharjo (2009), preservation effort means retaining the architectural heritage and traditional / ancient environment exactly like the original state. Because of the static nature of preservation, conservation efforts also require a dynamic conservation approach, which includes not only buildings but also the environment (conservation areas) and even historical cities .

One of the conservation efforts that can be done to preserve Kejek Tea is by making travel patterns.

\section{Materials and Methods}

The problem that will be discussed by researchers is a social and dynamic problem so research is conducted using descriptive qualitative methods. Gaining the data is done by conducting in-depth interviews, observation and documentation.

Aan Komariah and Djam'an Satori (2009: 22) suggest that qualitative research is research that emphasizes or focuses on quality or the most important thing from the nature of an item or service. The most important thing of a product or service is an event, phenomenon or social phenomenon that has the meaning behind the event that can be used as valuable learning for a 
development of theoretical concepts.

Meanwhile according to Bogdan and Taylor (1975) quoted by Moleong (2007: 6) suggested that qualitative methodology as a procedure or method of research that produces various kinds of descriptive data in the form of written or oral words from people and observable behavior.

This research makes the object of research, namely Kejek Tea with the subject of the research of the Kejek Tea maker in Garut Regency, precisely in Cigedug Village. Researchers aim to find out the uniqueness of traditional drinks that characterize Garut. In this study, researchers determined informants with purposive sampling techniques. According to Sugiyono (2014: 300) purposive sampling is a data source sampling technique with certain considerations. This particular consideration, for example the person is considered to know best about what is expected, or maybe that person as a ruler so that it will be easier for researchers to explore the object under study.

Data collection technique is a process that includes everything that needs to be done in research to get accurate data (data needed). To collect the data needed in this study, the authors take a number of techniques, including:

\subsection{Interview}

In-depth interviews are one of the parts included in data collection techniques. Usually this technique is used for qualitative research or research that produces descriptive data. An understanding of indepth interviews put forward by Burhan Bungin (2007: 53). According to Bungin, the meaning of in-depth interviews is: In-depth interview or interview is a process of obtaining data or information that is intended for research by question and answer, face to face between the interviewer and the informant or the person being interviewed, with or without using interview guidelines, where the interviewer and informants involved in social life for a relatively long time. Initial to end questions were obtained from informants. The information needed to describe the objective conditions is very effective with this method.

According to Moleong (2007) quoted from Patton (1980: 197) is by way of division, informal conversation interview and the approach uses general interview instructions, and open standard interviews.

The interview division conducted by Pattorn was based on the planning of the question. The interview method used is by conducting in-depth interviews with several informants in accordance with the objectives of the study. Interview techniques are carried out through direct and open question and answer with informants who are assisted by using an interview guide. In conducting in-depth interviews it is usually necessary to extract from the questions posed in-depth on a predetermined topic (based on the purpose and purpose of the interview) using open-ended questions. Excavation of questions carried out to find out their opinions based on the perspective of respondents in looking at an issue. This interview technique is carried out by an interviewer by interviewing one person face to face (face to face).

The usefulness or benefits of conducting in-depth interviews are:

a. The discussion topic of the problem in question can be complex or very sensitive.

b. Can dig up a complete and in-depth information about the attitudes, knowledge, views of respondents about the problem.

c. Respondents are scattered, the intention is that anyone can get an opportunity to be interviewed but based on the purpose and purpose of the research.

d. Respondents can freely answer all questions raised without pressure from others or shame in issuing their opinions.

e. The flow of questions in the 
interview can use guidelines (guide) or without using guidelines. If using the guide (guide), the flow of questions that have been made is not standard depending on the needs in the field while the weakness of this in-depth interview is the existence of emotional attachment between the two (the interviewer and the interviewee), therefore good cooperation is needed between the interviewer and the interviewee interviewed. By using Bahasa Indonesia that is appropriate.

\subsection{Observation}

The completeness of the data that can be obtained by observation makes observation become the right choice in this research. Observation is also used to make an initial approach to the object of observation. It is certainly important to provide convenience at the beginning of the study, before the interview is conducted and of course to describe the initial conditions of research in the field. Observation aims to get empirical information that is detailed and quite actual from the Bungin research analysis unit (2007: 115-117).

According to Moleong (2007) quoted from Guba and Lincoln (1981: 191-193) states the concept of the technique of observation in observation, namely:

First, this observation technique is based on direct experience. Both of these observation techniques also make it possible to see and observe themselves, then record behaviors and events as they occur in real life. Third, observation allows researchers to record events in situations related to proportional knowledge as well as knowledge directly obtained from data. Fourth, there are often doubts about the researcher, lest the data captured there is wrong or biased. The fifth is techniques of complicated situations. Complicated situations might occur if the researcher wants to pay attention to behavior at the same time. Sixth, in certain cases where other communication techniques are not possible, observation can be a useful tool.

It was concluded methodologically for the use of observation to optimize the ability of researchers in terms of motives, beliefs, concerns, unconscious behavior and habits, and so on. This observation allows the observer to see the world as seen by the object of research, living at the time, capturing cultural life from the point of view and the upbringing of the subjects at the time.

These observations are very important to be done by researchers, because researchers want to get results that are in accordance with the existing conditions in the field, namely researchers want to explore the traditional drink typical of Garut Regency, namely Kejek Tea which is able to be used as a business idea for the surrounding communities so as to be able to make the economy the area is better and is able to help attract the interest of tourists who want to visit Garut.

\subsection{Documentation}

Research conducted using a camera or video is nothing but as a verification of a culture that is being researched and observed. The presentation uses a photo then with text or caption. According to Moleong (2007: 217) this documentation or photo study can produce descriptive data which is quite valuable and is often used to examine subjective aspects and the results are often analyzed inductively and needed in qualitative research. The document according to Sugiyono (2007: 240) is a record of events that passed. The document used by researchers here is in the form of photos, as well as data about Tea Kejek. The results of research from observations and interviews will be more legitimate and can be trusted if supported by photographs.

Researchers use documentation studies in the form of photographs to complement existing data sources in the field to provide an overview of the data as an amplifier of the data that has been 
collected. Researchers chose this technique with the intention that the Kejek Tea traditional drink can be well documented through photographs so that the results of the study have clear data.

\subsubsection{Documentation Study}

Iskandar (2009: 135) states that the study of documentation is a technique of data collection through the collection of necessary documents related to the problem under study to be examined intensely so that it can support and increase trust and proof of a problem. As according to Irawan Soehartono (2000: 70), the study of documentation is a data collection technique that is shown to research subjects. In qualitative research, this technique is the main data collection tool because the verification of hypotheses is submitted logically and rationally through opinions, theories, or laws that are accepted, both supporting and helping the hypothesis.

Based on the above understanding that documentation is a source of data used to complement research, both in the form of written sources, films, pictures (photographs), and monumental works all of which provide information for the research process.

\subsection{Data Validity}

\subsubsection{Triangulation}

Data collection techniques, according to Sugiyono (2012: 241), triangulation is defined as a data collection technique that combines various existing data collection techniques and data sources. When a researcher collects data by triangulation, then the researcher actually collects data by triangulation and the research researcher collects data which at the same time examines data creatiability, that is checking data creatiability with data collection techniques and various data sources.

Researchers in triangulation using observation, in-depth interviews, questionnaire techniques and documentation for the same data source simultaneously.

\subsubsection{Data analysis}

Data analysis is one of the most important processes in research. Because, the process of data analysis is the process of finding data from various ways and analyzing them to find answers of the existing problems. This is as stated by several experts who explain about data analysis.

Like the concept of data analysis proposed by Sugiyono (2005: 62) . According to data analysis are:

"Data analysis is the process of looking for, looking at and systematically compiling data obtained from interviews, field notes and documentation, by organizing data into categories, breaking down into units, synthesizing, organizing into patterns of choosing which are important and which will be studied and made conclusions so that they can be easily understood by themselves and others ".

According to Miles \& Huberman (1984: 23) in Emzir (2012) there are three kinds of activities in qualitative data analysis, namely:

\subsubsection{Data reduction}

Data reduction refers to the process of selecting, focusing, simplifying, abstracting and transforming "raw data" that occurs in written report records. Data reduction is not separate from the analysis. It is part of the analysis. The researchers' choices of pieces of data to be coded to be pulled out and summarized the patterns of a number of pieces, what the story is developing, are all analytical choices. Data reduction is a form of analysis that sharpens, chooses, focuses, discards and arranges data in a way where the final conclusions can be drawn and verified.

\subsubsection{Data Model (Data Display)}

The second step of the data analysis activity is the data model, the word defines "model" as a compiled collection of information and allows the description of 
conclusions by taking action. The model includes various types of matrices, graphics, networks and charts. All are designed to compile information that is arranged in a directly accessible, practical form so that the researcher can see what is happening and can well illustrate the conclusions justified and move to the next phase of the analysis the model might suggest useful.

\subsubsection{Conclusion Drawing (Conclusion Drawing Verification)}

The final step in the data collection process is drawing conclusions. This conclusion was drawn up in a concise and easy format with reference to the research objectives. The researcher draws conclusions from various information which are obtained during the research on the preservation of the traditional Kejek Tea as a gastronomic legacy of Garut Regency.

\section{Results and Discussion}

This study aims to introduce and preserve Kejek Tea as a gastronomic legacy of Garut Regency. Therefore, in this study, the first will be an overview of the history, existence and development of Kejek Tea from the past to the present. Second, the gastronomic component of Kejek Tea. Third, the author will describe the efforts and roles of the community and the government in preserving Kejek Tea as a gastronomic legacy of Garut Regency.

The existence of Kejek Tea is not known with certainty, but has been around since the Dutch era. From Kejek tea, teatime formed Cigedug society, Garut, known as "Tradition Nyaneut". Nyaneut is taken from the word "haneut" in Sundanese which means warm. The traditional Kejek Tea drink is not very popular among the wider community, especially in the younger generation. This is due to the lack of promotion carried out by Kejek Tea producers and their governments which has made this tea not as well-known as other green teas.

In addition to this, there are things that make the existence of Kejek Tea considered less in the first community, namely, in terms of marketing that is not brave enough to supply this tea to a souvenir or supermarket. Second, the lack of innovative packaging made so that consumers are not interested in consuming it.

At present, there is only one Kejek Tea producer that still runs this tea business to date with its traditional processing. This can be used as an advantage owned by Kejek Tea to attract the interest of the community and local tourists. So the Kejek Tea producers and the government should be more serious in efforts to preserve this Kejek Tea so that tea that has existed since the Dutch era will continue to exist.

The author makes an administrative map of Garut Regency and the distribution map of Tea Kejek producers in Kec. Cigedug, Garut Regency.

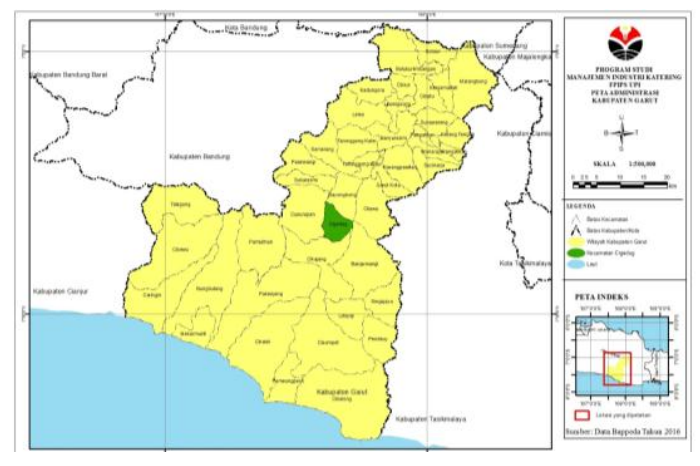

Soure: Sarah Nur Hamidah (2019)

Figure 1. Garut District Administration Map

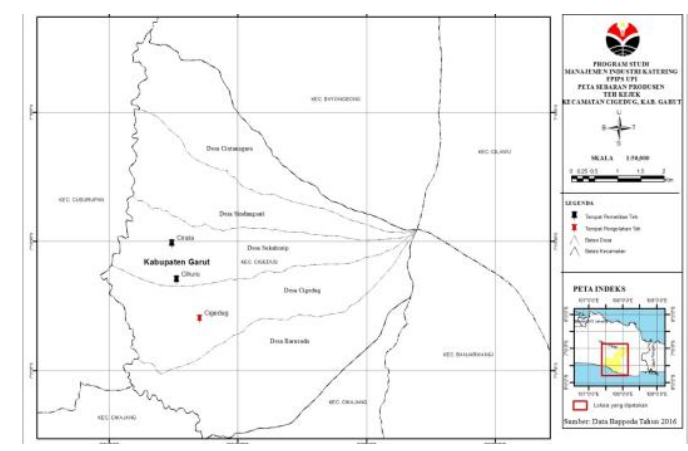

Sumber: Sarah Nur Hamidah (2019)

Figure 2. Map of the Distribution of Tea Sejek Prosedurs in Cigedug District, Garut District

Indonesia has a wealth of traditional 
foods and drinks. One of them is Kejek Tea, a traditional tea that still maintains a distinctive taste in Cigedug Village, which currently has a very poor presence in the wider community. Seeing the current condition of Kejek Tea, it is necessary to preserve it. Tourist attractions are tourist activities in the form of all matters relating to the natural environment, culture, and other activities related to tourist activities that are able to attract tourists.

This can be a consideration to be made as an effort to preserve Kejek Tea traditional drinks in West Java, especially in Garut Regency and Cigedug District. It is expected that traditional Kejek Tea can be an attraction for tourist destinations.

The effort made by the author is by making a pattern of tourist visits to the Pak Oos Kejek Tea Factory and helping to make Kejek Tea packaging that is more attractive to consumers.

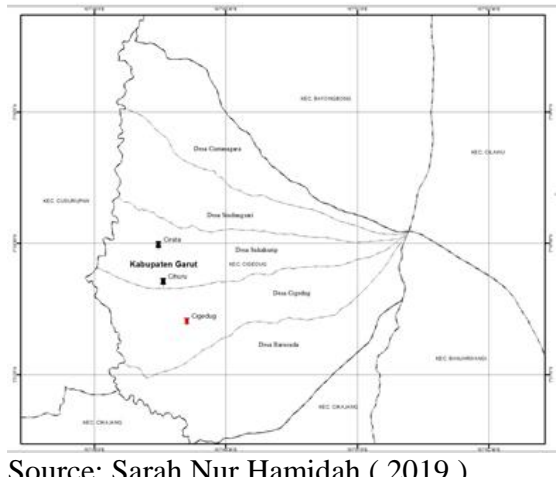

Figure 3. Pattern Visit Tourism to Kejek Tea Pak Oos Factory

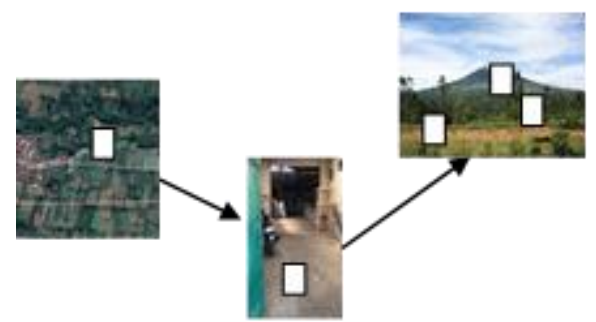

Source: Sarah Nur Hamidah ( 019: 109)

Figure 4. Layout Room Factory Tea Kejek Pak Oos

The capacity of the room is only for 5 visitors and 1 tour guide.

Table 1. Schedule of Visiting Tourism Visits to the Tea Factory, Pak Oos

\begin{tabular}{|c|c|c|c|c|}
\hline Time. & Duration & Location & Activity & Information \\
\hline $8: 00$ & $\begin{array}{c}5-10 \\
\text { Minutes }\end{array}$ & $\begin{array}{l}\text { ( } 1 \text { ) Parking } \\
\text { Lots, Cihuru } \\
\text { Tea } \\
\text { Plantations }\end{array}$ & $\begin{array}{l}\text { Get Off The } \\
\text { Vehicle }\end{array}$ & Walk To The Cihuru Tea Plantation \\
\hline $8: 10-08.40$ & $\begin{array}{l}15-30 \\
\text { Minutes }\end{array}$ & $\begin{array}{l}\text { ( } 2 \text { ) Cihuru } \\
\text { Tea } \\
\text { Plantation }\end{array}$ & $\begin{array}{l}\text { Introduction } \\
\text { To Tea And } \\
\text { Tea Picking }\end{array}$ & $\begin{array}{l}\text { Tourists Are Educated To } \\
\text { Recognize The Type Of The }\end{array}$ \\
\hline 8:40 A.M. - 8.50 A.M. & $\begin{array}{c}10 \\
\text { Minutes }\end{array}$ & $\begin{array}{ll}\text { ( } 3 \text { ) Pak } & \text { Oos } \\
\text { Kejek } & \text { Tea } \\
\text { Factory } & \end{array}$ & $\begin{array}{l}\text { Introduction } \\
\text { And } \\
\text { Explanation } \\
\text { Of Kejek Tea }\end{array}$ & $\begin{array}{l}\text { Tourists Are Educated To Know } \\
\text { The History Of Tea Kejek }\end{array}$ \\
\hline $8.50-09.20$ & $\begin{array}{c}20 \\
\text { Minutes }\end{array}$ & $\begin{array}{l}\text { ( } 4 \text { ) Pak } \text { Oos } \\
\text { Kejek Tea } \\
\text { Factory }\end{array}$ & $\begin{array}{l}\text { See And } \\
\text { Explain The } \\
\text { Tools And } \\
\text { Materials } \\
\text { Used To Make } \\
\text { Kejek Tea }\end{array}$ & $\begin{array}{l}\text { Tourists See And Listen To An } \\
\text { Explanation Of The Tools And } \\
\text { Materials Used For Making Kejek } \\
\text { Tea }\end{array}$ \\
\hline 9:20 A.M. - 10:00 & $\begin{array}{c}30-40 \\
\text { Minutes }\end{array}$ & $\begin{array}{ll}\text { ( } 5 \text { ) Pak } & \text { Oos } \\
\text { Kejek } & \text { Tea } \\
\text { Factory } & \end{array}$ & $\begin{array}{l}\text { Simulation Of } \\
\text { Making Kejek } \\
\text { Tea }\end{array}$ & $\begin{array}{l}\text { Tourists Are Given An Explanation } \\
\text { Of The Process Of Making Kejek } \\
\text { Tea And Take Turns Trying The } \\
\text { Processing Directly }\end{array}$ \\
\hline $10 \mathrm{Am}-11.20$ & $\begin{array}{l}60-80 \\
\text { Minutes }\end{array}$ & $\begin{array}{l}\text { (6) The Foot } \\
\text { Of Mount } \\
\text { Cikuray }\end{array}$ & $\begin{array}{l}\text { Nyaneut } \\
\text { Tradition }\end{array}$ & $\begin{array}{l}\text { Tourists Are Invited To Enjoy Tea } \\
\text { Served With A Special } \\
\text { Presentation Of Kejek Tea Which }\end{array}$ \\
\hline
\end{tabular}




\begin{tabular}{|c|c|c|c|c|}
\hline Time. & Duration & Location & Activity & Information \\
\hline $11.20-11.30$ & $\begin{array}{c}10 \\
\text { Minutes }\end{array}$ & $\begin{array}{l}\text { (7) The Foot } \\
\text { Of Mount } \\
\text { Cikurav }\end{array}$ & $\begin{array}{l}\text { Distribution } \\
\text { Of Kejek Tea }\end{array}$ & $\begin{array}{l}\text { Is Served With Tea Companions } \\
\text { Such As Cassava, Bananas, Beans } \\
\text { Which Are All Boiled. } \\
\text { Tourists Are Given Souvenirs } \\
\text { In The Form Of Kejek Tea }\end{array}$ \\
\hline 11:30 P.M. & 5 Minutes & $\begin{array}{l}\text { (8) Parking } \\
\text { Lot At The } \\
\text { Foot Of } \\
\text { Cikuray } \\
\text { Mountain }\end{array}$ & Return & $\begin{array}{l}\text { Tourists Have Finished Taking The } \\
\text { Tour Of Teh Kejek Pak Oos And } \\
\text { Taken Home }\end{array}$ \\
\hline
\end{tabular}

Source: Sarah Nur Hamidah ( 2019)

Table 1. above contains the time column, duration, location of activities, and information. For the time and duration columns show how long the activities can be carried out by tourists. Then the location column shows where the tourists are when the activity takes place. And the activity column shows how the activity took place with a detailed explanation that is explained in the information column. With a visit to the Kejek Tea gastronomic tour, it is hoped that the traditional Kejek Tea can be better known to the wider community.

Table 2. Details of Visit Pattern Cost

\begin{tabular}{ll}
\hline \multicolumn{1}{c}{ Information } & \multicolumn{1}{c}{ Price } \\
\hline Tickets take tea & Rp. 100,000/ \\
picking, tea & person \\
making, tea & \\
drinking & \\
traditions, and & \\
souvenirs in the & \\
form of Kejek Tea & \\
(200gr). &
\end{tabular}

\begin{tabular}{cl} 
Total cost & $\begin{array}{l}\text { Rp. 100,000/ } \\
\text { person }\end{array}$ \\
\hline Source: Sarah Nur Hamidah (2019) &
\end{tabular}

Table 2. above that the total cost required by tourists is $\mathrm{Rp} .100,000$, - the fee includes transportation, class picking tea tickets, making tea, tea drinking traditions, and souvenirs in the form of Kejek Tea (200gr).

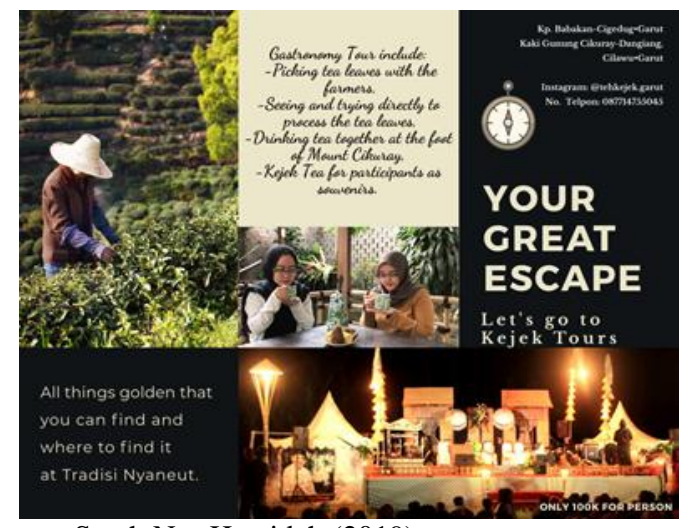

Source: Sarah Nur Hamidah (2019)

Figure 5. Kejek Tea Tourism Brochure

Based on Figure 5 , then. the pattern of trips made to the Pak Oos Kejek Tea Factory is first to go picking tea leaves. Second, proceed with the way to see and pay attention to the next try to practice how to process Kejek Tea. Third, drink tea together at the foot of Cikuray Mountain and distribute souvenirs in the form of Kejek Tea (200gr).

Here are the Kejek Tea packages that have been made by the author in order to help preserve Kejek Tea by making more attractive packaging:

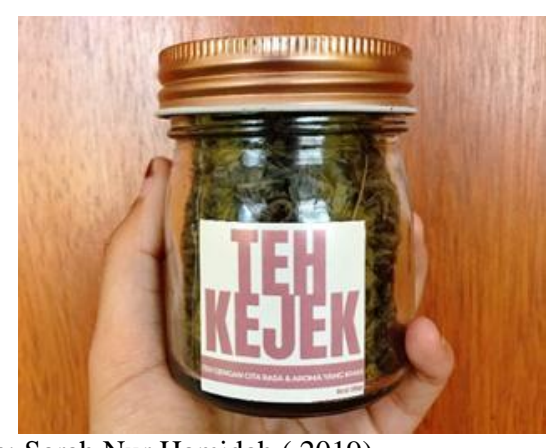

Source: Sarah Nur Hamidah ( 2019)

Figure 6. Front Cover Packaging Kejek Tea 


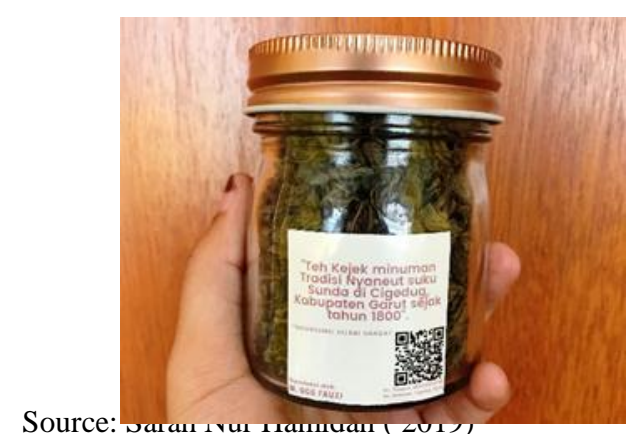

Figure 7. Back Cover Packaging Kejek Tea

\section{Conclusions}

Based on the research results obtained by the author and has been described in the previous chapter on the Conservation of Tea Kejek as a Gastronomic Legacy of Garut Regency, it can be concluded as follows:

a. Kejek tea is a Cigedug typical tea which is processed manually with traditional equipment. Kejek tea has been around since the Dutch era. The name Kejek was taken because of the manufacturing process that uses foot power. Kejek in Indonesian means being stepped on, is done so that Kejek Tea is easily recognized by the wider community because the existence of Kejek Tea among the public is currently very less well known. Kejek tea is only produced in Cigedug Village, Cigedug District, Bandung Regency.

b. The process of Kejek Tea is quite simple, that is, the tea leaves that have been roasted are mocked, and then the process is salted or evaporated, after which the tea leaves are roasted again, then the tea is ready to be sorted according to its quality and ready for sale.

c. The effort to preserve Kejek Tea by the researchers is to make Kejek Tea one of the gastronomic tourism attractions in Cigedug District by creating a gastronomic tour pattern and making attractive and innovative packaging. This effort aims to maintain the existence of Kejek Tea so it will not become extinct and remain

\section{References}

Alma, B. (2007). Manajemen Pemasaran dan Pemasaran Jasa. Bandung: CV. Alfabeta.

Assuari, S. (2008). Manajemen Produksi dan Operasi. Jakarta: Fakultas Ekonomi Universitas Indonesia.

Badan Pusat Statistik Kabupaten Garut. (2018). Kecamatan Cigedug Dalam Angka Cigedug In Figures 2018. Garut: BPS Kabupaten Garut.

Budiharjo, E. (2009). Penataan Ruang dan Pembangunan Perkotaan. Bandung: PT. Alumni.

Bungin, B. (2007). Penelitian Kualitatif: Komunikasi, Ekonomi, Kebijakan Publik, dan Ilmu Sosial Lainnya. Jakarta: Putra Grafika.

Chaedar. (2006). Pokoknya Kualitatif. Jakarta: Pustaka Jaya.

Dian Sundari, d. (2009). Toksisitas Akut (LD50) dan Uji Gelagat Ekstra Daun Teh Hijau (Camellia Sinesis) Pada Mencit. Jurnal Media Penelitian dan Pengembangan Kesehatan, 198.

Diansyah, A. (2011). Eksistensi Damang Sebagai Hakim Perdamaian Adat Pada Masyarakat Suku Dayak Di Palangkaraya. Denpasar: Program Pascasarjana.

Endarmoko, E. (2006). Kamus Bahasa Indonesia. Jakarta: EGC.

Erdward, I. (1991). Tourism Planning An Integrated and Sustainable Development Approach. New York: Van Nostrand Reinhold.

Huberman, M. d. (1984). Analisis Data Kualitatif. Jakarta: Universitas Indonesia.

Indonesia, R. (2009). Undang-undang Republik Indonesia Nomor 10 Tahun 2009 Tentang Kepariwisataan. Jakarta: Sekretariat Negara.

Iskandar. (2009). Metode Penelitian Kualitatif. Jakarta: Gaung Persada (GP Press).

J.J, S. (1987). Pariwisata Indonesia Ssejarah dan Prospeknya. Yogyakarta: Kanisius.

K.B, M. (1990). Pricing, Making Profitable 
Decissions (Second Edition ed.). New York: McGraw-Hill.

Keller, K. d. (2009). Manajemen Pemasaran (Edisi ke 13 ed., Vol. Jilid 1). Jakarta: Erlangga.

Khomsan, A. (2006). Sehat dengan Makanan Berkhasiat. (I. Suhanda, Ed.) Bandung: Penerbit Buku.

Legault, R. E. (2005). A Definitionof Quality for Total Customer Satisfaction: The Bridge between Manufacturer and Customer. Sam Advanced Management Journal, 18.

Liesnoor, J. d. (2001). Desain dan Komposisi Peta Tematik. Semarang: CV. Indoprint.

Malik, J. J. (2010). Implementasi Teknologi Barcode Dalam Dunia Bisnis. Yogyakarta: ANDI Offset.

Martin, L. C. (2007). Tea: The Drink That Changed The World. Tuttle Publishing.

Moleong, J. (2007). Metode Penelitian Kualitatif. Bandung: PT. Remaja Rosdakarya Offset.

Nastain, M. (2007). Branding dan Eksistensi Produk (Kajian Teoritik Konsep Branding dan Tantangan Eksistensi Produk).

Ningsih, C. (2014). Sinergitas Industri Kreatif Berbasis Pariwisata Dengan Strategi Pembangunan Industri Nasional Menuju Globalisasi. Jurnal Penelitian dan Pengembangan Resort \& Leisure.

NIOS. (2018). Pariwisata Budaya.

Nuraeni, C. N. (2018). Developing Strategy of Chinatown as a Halal. 3rd International Seminar on Tourism (ISOT 2018), 43.

Oka, Y. (1996). Pengantar Ilmu Pariwisata. Bandung: Angkasa.

Pariwisata, K. (2015). Rencana Strategis: Pengembangan Destinasi dan Industri Pariwisata 2015-2019. Jakarta.

Pariwisata, K. K. (2010). Rencana Strategis: Kementrian Kebudayaan dan Pariwisata tahun 2010-2014. Jakarta.

Pontoh, N. K. (1992). Preservasi dan Konservasi Suatu Tinjauan Teori
Perancangan Kota. Jurnal PWK, IV (6), 34-39.

Ryan, C. \&. (2012). Analyzing the Evolution of Singapore's World Gourment Summit: An example of gastronomic tourism. International Journal of Hospitality Manajemen, 309-318.

Saladin, D. (2006). Manajemen Pemasaran (Edisi Keempat ed.). Bandung: Linda Karya.

Sari, D. T. (2017). Gastronomy Tourism Attraction in Ternate City. 1st International Conference on Tourism Gastronomy and Tourist Destination (ICTGTD 2016) , 28.

Satori, A. K. (2009). Metodologi Penelitian Kualitatif. Bandung: Alfabeta.

Setiawan, T. (2009). Mempelajari Produksi Teh Hitam Ortodox di PT. Perkebunan Nusantara VIII Cisaruni, Garut Jawa Barat. Bogor: Jurusan Teknik Pertanian. Fakultas Teknologi Pertanian. IPB.

Soehartono, I. (2000). Metode Penelitian Sosial. Bandung: PT. Remaja Rosdakarya Offset.

Sugiyono. (2005). Metode Penelitian Pendidikan Pendekatan Kuantitatif, Kualitatif, dan R\&D. Bandung: Alfabeta.

Sugiyono. (2007). Metode Penelitian Pendidikan Pendekatan Kuantitatif, Kualitatif, dan R\&D. Bandung: Alfabeta.

Sugiyono. (2012). Metode Penelitian Pendidikan Pendekatan Kuantitatif, Kualitatif, dan R\&D. Bandung: Alfabeta.

Sugiyono. (2014). Metode Penelitian Pendidikan Pendekatan Kuantitatif, Kualitatif, dan R\&D. Bandung: Alfabeta.

Sujayanto, G. (2008). Khasiat Teh Untuk Kesehatan dan Kecantikan. Jakarta: ITB.

Syah, A. N. (2006). Taklukan Penyakit Dengan Teh Hijau. Jakarta: Agro Media Pustaka.

T, R. N. (2015). Pengaruh Kemasan dan 
Harga Pada Keputusan Pembelian Minuman Isotonik. 3.

Turgarini, D. (2018). Gastronomi Sunda Sebagai Daya Tarik Wisata Kota Bandung.

Wahab, S. (2003). Industri Pariwisata Dan Peluang Kesempatan Kerja. Jakarta: PT.
Pertja.

Wijayanti, T. (2012). Management Marketing Plan. Jakarta: PT. Elex Media Komputindo.

Wirya, I. (1999). Kemasan Yang Menjual. Jakarta: PT. Gramedia Pustaka Umum. 